\title{
CORRESPONDENCE
}

Migraine in childhood

M A Salmon, FRCPED, and others...... 1481

Routine procedures in general

anaesthesia

G C Steel, fFarcs . . . . . . . . . . 1481

Standards for surgical therapeutic

trials

D H Spodick, MD, and others........ 1482

Uniform style for biomedical journals

K G M M Alberti, MRCPATH; R Hole, FRCS 1482

Interrelated factors in hypertensive patients

V M Hawthorne, FRCPGLAS, and Mary

Smalls, BSC; J H Fuller, MRCP, and others.. 1483

The Stomach Cancer Group

P F M Wrigley, MRCP, and V S Brookes,

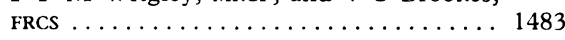

Television medicine

J Apley, FrCP................ 1483

Treatment of tuberculosis

A Seaton, FRCP.............. 1484

Diuretics in the elderly

S Waldek, MRCP; D M Burley, MRCP.... 1484

Sulphinpyrazone after myocardial

infarction

S H Kane, MD . . . . . . . . . . . . 1484

Plasma urate changes in

pre-eclampsia

C W G Redman, MRCP, and J Bonnar,

FRCOG .................... 1484

Rubella vaccination

Leonora A Crawford, MFCM.......... 1485
Coronary heart disease and male sex hormones

Ingrid $\mathrm{L}$ Waldron, PHD

Cetiprin (emepronium bromide) in patients with prostatism

E S Glen, FRCSED; A D Lauder, MB...... 1485

Stricture of oesophagus associated with ankylosing spondylitis

A P Weetman, MB...

Is pancreatic isotope scanning worth while?

P B Cotton, FRCP...

Psychiatric problems after mastectomy

H G Kinnell, MRCPSYCH . . . . . . . . . . . 148

Cimetidine and protective effect of mucus in gastric ulcer

M Guslandi, MD, and others. . . .

Painful young bellies

I H J Bourne, FRCGP; H A Goudarzi, FRCs 1486

"Innovation in the Pharmaceutical

Industry"

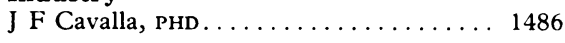

Plasmapheresis

Daisy Obeid, MB, and Paula Cotter, MD . . 1486

Vincristine-induced neuropathy in

lymphomas

Sylvia $M$ Watkins, DM, and J P Griffin,

PHD, MB................... 1487

Geriatric beds

R L G Sutcliffe, FRCPED.

Ultrasound and work load in the radiology department

B M Gompels, FRCR. .
Pituitary tumours and pregnancy

K W Hancock, MRCOG, and others...

Factors influencing the incidence of

neonatal jaundice

B S B Wood, frCP............. 1488

Myelography and lumbar venography

R G Grainger, FRCP, FRCR . . . . . . . . . 1488

Pilots' hearts

J H McKillop, MRCP, and others....... 1488

Surgery for intermittent claudication

C V Ruckley, fRCSED . . . . . . . . . . . . 1489

Umbilical cord prolapse

T Vago, MD . . . . . . . . . . . . . . . . . 1489

Cough mixtures

D Adler, Mrcs . . . . . . . . . . . . . 1489

A British "Doctors' Ten"

R C Goodfellow, мB . . . . . . . . . . . . . . 1489

Shortage specialties

J L C Dall, FRCPGLAS . . . . . . . . . . . . 1489

BMA and the Abortion Act

D C Flint..............

New consultant contract

P W Fisher, FRCP; G Johns, FFARCS; A E

Carter, frCs . . . . . . . . . . . . 1490

Setting an example

J S Elkington, FRCS, and Gillian Elkington 1491

Economy in drug prescribing

J D Williamson, MRCGP; D Sapsford, MB . . 1491

Future of British anaesthetics

$M$ D A Vickers, fFARCS, and $M$ Rosen,

1491

Abuse of Form Med 3

$\mathrm{J} M$ Anderson, $M B$

Pay of vocational trainees

M H Owen, MB.................. 1491
Correspondents are urged to write briefly so that readers may be offered as wide a selection of letters as possible. So many are being received that the omission of some is inevitable. Letters must be signed personally by all their authors.

\section{Migraine in childhood}

SIR,-The frequency of childhood migraine is poorly appreciated in many paediatric textbooks, so we the undersigned, who are concerned at the lack of understanding of migraine in children, have been discussing the topic at two meetings organised by the British Migraine Association. We would like to draw the attention of our colleagues to our conclusions and open the subject to discussion.

In 1962 the Ad Hoc Committee on Classification of Headache ${ }^{1}$ defined migraine as "Recurrent attacks of headache, widely varied in intensity, frequency and duration. The attacks are commonly unilateral in onset; are usually associated with anorexia and, sometimes, with nausea and vomiting; in some are preceded by, or associated with, conspicuous sensory, motor and mood disturbances; and are often familial." This definition is widely accepted. It is, however, founded on presentations of migraine in adults, and does not cover certain aspects of the condition as it presents in children.

We found migraine in childhood difficult to define. It may present from early infancy on, and under the age of 10 has an equal sex incidence. All known types occur, classical and common migraine being the most frequent presentations. Migraine of so-called basilar, hemiplegic, and ophthalmoplegic type can also be recognised from infancy onwards.

Typically, migraine attacks in childhood have an acute onset with headache, commonly frontal, accompanied by some of the following features: nausea with or without vomiting, anorexia, malaise, pallor, and a desire to sleep. Less commonly there may be eye pain, profound lethargy with or without hypotonia, sensory (commonly visual), motor, or mood disturbance, ketosis, and pyrexia. Attacks are usually over within $24 \mathrm{~h}$, but episodes may cluster. In some children headache may be insignificant and the systemic upset predominant; such cases are not always readily diagnosed or accepted as migraine.

There are various symptom complexes which may be associated with migraine in childhood, although the validity of the relationship is not clearly established. These include: (a) Recurrent abdominal pain-colicky or epigastric aching; the pain is short-lived and central and may be accompanied by abdominal distension, nausea, and vomiting; the vomiting may be biliary, and lead to ketosis and de- hydration (cyclical vomiting). (b) Episodic malaise, with anorexia, pallor, fever, and pale stools.

Our studies of this subject are continuing and we would appreciate observations.

\begin{tabular}{|c|c|}
\hline MICHAEL SALMON & P GUZDER \\
\hline KaTHARINA DALTON & E WATERS \\
\hline MARGARET SWEENEY & Michael DaltoN \\
\hline JUDITH HOCKADAY & BARRY LEWIS \\
\hline JOHN WILSON & D HOOPER \\
\hline $\begin{array}{r}\text { W FoRSYTHE } \\
\text { K HAY }\end{array}$ & MAUREen DaLton \\
\hline
\end{tabular}

${ }^{1}$ Friedman, A P, et al, Archives of Neurology, 1962, 6, 73.

\section{Routine procedures in general} anaesthesia

SIR,-I am grateful to those who have commented on my Personal View (22 April, $p$ 1049) both through your columns and in personal letters: in the latter case I am particularly grateful for the kind comments that have been made.

Dr M A Thompson's pleasantly temperate letter (13 May, p 1275) suggests that my communication illustrates the changes between anaesthesia as it used to be and as it is now, which may well be the case. This change, if I interpret his letter correctly, is exemplified by the increased use of relaxants and of the endotracheal tube in cases in which the latter is not necessarily essential to the maintenance of a good airway. Up to the time of my 